Article

\title{
Video Production in Elementary Teacher Education as a Critical Digital Literacy Practice
}

\author{
Diane Watt \\ Faculty of Education, University of Ottawa, Ottawa, ON K1N 6N5, Canada; E-Mail: dwatt@uottawa.ca
}

Submitted: 14 January 2019 | Accepted: 14 March 2019 | Published: 11 June 2019

\begin{abstract}
This article reports on a two-year, funded, qualitative inquiry into the challenges and possibilities of integrating video production into pre-service teacher education as a critical digital literacy practice. This includes the skills, knowledge, and dispositions that lead to ability to critique and create digital texts that interrogate the self, the other, and the world (Ávila \& Zacher Pandya, 2013). Video making holds out enormous potential given our increasingly diverse classrooms and the growing need to have students connect and collaborate within their own communities and globally (Dwyer, 2016; Ontario Ministry of Education, 2015, 2016; Spires, Paul, Himes, \& Yuan, 2018; Watt, 2017, 2018; Watt, Abdulqadir, Siyad, \& Hujaleh, 2019). Video is especially significant in light of the fact that it is replacing print text as a dominant mode of communication (Manjou, 2018). Multimodal composing such as video production is, in fact, considered by some to be the essential 21st century literacy (Miller \& McVee, 2012), but much remains to be done to bring digital technologies as literacy into the elementary classroom. Qualitative data includes a focus group, questionnaires, observations, and content analysis of teacher candidate videos and instructional plans. This study considers how video production can be integrated into teacher education programs to engage cross-curricular expectations and critical digital literacy perspectives. It responds to the pressing question of how to do teacher education differently in the digital age.
\end{abstract}

\section{Keywords}

critical digital literacy; curriculum integration; New Literacies; teacher education; technology; video production

\section{Issue}

This article is part of the issue "Critical Perspectives on Digital Literacies: Creating a Path Forward", edited by Hiller A. Spires (North Carolina State University, USA).

(C) 2019 by the author; licensee Cogitatio (Lisbon, Portugal). This article is licensed under a Creative Commons Attribution 4.0 International License (CC BY).

Video making needs to trickle down into the younger grades because it is how we are communicating now. (Teacher candidate)

\section{Introduction}

The nature of reading, writing, and video communication have fundamentally transformed due to the Internet. The literacy practices needed to function fully in the world today continuously expand as technologies advance. Teachers, teacher educators, and literacy researchers are struggling to keep pace. Even though digital literacy is mandated in every Canadian province, change in the classroom has tended to be slow (Brown, 2017; Daniels, Jacobsen, Varnhagen, \& Friesen, 2013;
Hoechsmann \& DeWaard, 2015; Lotherington, Fisher, Jenson, \& Lindo, 2016). This may be understandable given the enormity of the task. Some of the challenges to integration include: a lack of technology in classrooms, inadequate teacher education and in-service professional learning, teacher attitudes and beliefs (Hagood, 2013), an enduring adherence to traditional notions of literacy, and a persistent view of technologies as an "addon" rather than a central component of literacy today (Daniels et al., 2013; Hoechsmann \& DeWaard, 2015).

At the same time, children and youth are often innovators of New Literacy practices as they engage with technologies outside school hours (Ito et al., 2009; Sanford, Rogers, \& Kendrick, 2014; Watt, Abdulqadir, Hujaleh, \& Siyad, 2019; Watt, Abdulqadir, Siyad \& Hujaleh, 2019). 
There is generally a gap between the literacies practices students encounter in school and those they engage with on their own time, which puts schools at risk of becoming less engaging and relevant. We have entered into a new era of literacies, and New Literacies (Leu, Kinzer, Coiro, Castek, \& Henry, 2013) theory, research, and practices are needed to negotiate this terrain. The current study focuses on how preservice teacher understandings of what counts as literacy dramatically shift after a brief hands-on video making workshop, followed by collaboratively designing an instructional plan that integrates student video production. This research takes place at a large Canadian university in the province of Ontario, but findings may be relevant for techer education programs across Canada and beyond.

\section{From Critical Literacies to Critical Digital Literacies}

Proponents of new and multiliteracies studies regard literacy as a collection of emerging practices for communicating in diverse and multiple social and cultural contexts (Cope \& Kalantzis, 2000; Lankshear \& Knobel, 2011; New London Group, 1996). "New Literacies" (Leu et al., 2013) has been proposed as an umbrella term to bring together diverse areas of research, theory, and practice within the ever-expanding field. Alongside traditional print text, New Literacies theory and pedagogies embrace different modes of meaning making (i.e., multimodal)-including visual, audio, spatial, and gestural (Kress, 2010). This broadened notion of literacy accounts for the expanded role digital technologies play in everyday life, including increased contact with difference both online and face-toface. Multiliteracies pedagogy in teacher education has always been based on principles of social justice and equity, and critical literacies are also an important component of New Literacies theory and practice.

Definitions of digital literacy also encompass a broad and evolving range of topics and issues related to Internet use. As Spires (2018) suggests, there is no consensus on a framework for digital literacies that adequately meets the demands of our contemporary global society. Digital literacies are shaped and defined according to the sociocultural contexts in which they occur, and are continuously expanding as new technologies are introduced. According to a recent survey, those of most concern to Canadian educators include: online safety, appropriate online behaviour, dealing with cyberbullying, privacy issues, and the accuracy of online information (Johnson, Riel, \& Froese-Germain, 2016), and educational resources are being developed to address these areas (e.g., Common Sense Education, 2018; Media Smarts, 2016). However, this study looks at the potential of creating and communicating digital content to engage curriculum and critical perspectives in the Freirian sense (Freire, 2000) of critical literacy. Traditionally, the focus has been on the skills, dispositions, and knowledges needed to critically examine power relations through texts. The term, "critical digital literacies" marks a shift to include digi- tal spaces and tools. In this study, video production is thus conceptualized as a critical digital literacy practice. Video technologies allow individuals to "engage with, respond to, and create both text-based and multimodal forms of literacy" (Ávila \& Zacher Pandya, 2013, p. 3). Video production is an increasingly significant, yet underappreciated means to foster critical literacies in educational contexts.

Vasquez's (2013) perspectives on critical literacy are also relevant for both the elementary educational context and the teacher education classroom. She does not view critical literacy as an add-on, "but a frame through which to participate in the world" (p. 82). It is not a topic to be taken up, but a lens for teaching across the curriculum. For Vasquez, this implies that "issues and topics that capture students' interests as they participate in the world around them should be used as text to build a curriculum that has significance in their lives" (p. 82). She argues students' cultural identities, lived experiences, and digital literacy practices should be engaged to construct meaningful curriculum. This view resonates strongly with the assumptions underlying the current study.

\section{Making the Case for Video}

Everyday life, learning, and citizenship today require children and youth to not only be critical consumers of information, but also collaborators in the production of knowledge (Jenkins, Purushotma, Weigel, Clinton, \& Robinson, 2006; Ontario Ministry of Education, 2006). Although digital technologies have become an integral part of the social, economic, and political landscape, their use in classrooms remains underdeveloped (Brown, 2017; Johnson et al., 2016; Lotherington et al., 2016; Miller, 2013; Watt, 2017). Lotherington et al. (2016) point out most teacher education programs in Ontario continue to offer only "cursory and superficial" (p. 72), rather than systematic, approaches to the integration of digital technologies. The focus tends to be on technology instruction rather than on how technologies facilitate multimodal learning processes. Brown (2017) similarly finds that the infusion of digital technologies into lesson design is largely lacking in pre-service teacher education across Canada.

Mobile devices and editing software now make it possible to shoot and edit video anywhere, and more needs to be done with video to engage both familiar and new forms of student learning processes (Miller, 2013; Steeves, 2014). Traditional beliefs about what counts as literacy are a key impediment to integrating other modalities such as video into classroom pedagogy (Miller, 2013). A focus on teachers' attitudes toward literacy and learning, however, may lead to change. Handson workshops with technologies combined with reflection on multimodal forms of learning may move teachers beyond the belief in a single mode-traditional print literacy. Such experiences help teachers adopt what Bailey (2006) refers to as, "a New Literacies stance." This con- 
ceptualization accommodates print literacy beliefs and values, while viewing literacy as dynamic and able to change with new social realities, such as the "digital turn" (Mills, 2010) taking place in literacies research. A New Literacies stance means developing new attitudes regarding the nature, significance, and value of multimodal texts, while recognizing that students who grow up with technology may be quite adept at collaborative learning. To bring critical digital literacy practices into the classroom thus implies challenging teacher attitudes toward, and beliefs about, multimodal literacies, how students learn using technologies outside of school, and what counts as knowing in the digital age (Miller, 2013 p. 404).

In addition, although children and youth are comfortable with these techonologies, they are not using them to full educational advantage (Miller, 2013). This is confirmed by a national survey (Steeves, 2014) of 5,426 students in grades 4 to 11 , that considers the role of networked technologies in the lives of Canadian youth. They are "confident and enthusiastic users" (p. 3) of networked technologies, but do not use them to their full potential. For example, although $75 \%$ of respondants share videos on YouTube, fully 67\% report that they do not creatively use digital media such as posting homemade videos online. This suggests students are major consumers of digital video texts, but seldom utilize this influential medium to create their own messages. Digital and media literacy require students to have the capacity to both critically read and produce digital texts.

Research also indicates students are more likely to succeed academically if they see themselves represented in the school curriculum (Dei, James, James-Wilson, Karumanchery, \& Zine, 2000; Ontario Ministry of Education, 2009b). Even in less culturally diverse classrooms students need to be exposed to a wide range of identities and perspectives to develop the ability to negotiate difference in their daily lives, both face-to-face and online. Canada is a multicultural society where respect for diversity and equity are core values even if this will always be an ongoing process. While making videos and designing instructional plans during the video production workshops, teacher candidates also have the opportunity to work with two Muslim female YouTubers from the local Somali-Canadian community. Their very prescence in the classroom as guest speakers and workshop leaders provokes an unsettling of assumptions, for Muslim women are often the subject of media representations rather than producers of knowledge (Watt, 2011a, 2011b, 2012, 2016b). Power relations are disrupted by having racialized black, Muslim, female, youth YouTubers from a community at risk of marginalization, as media experts.

Although a recent study (Johnson et al., 2016) indicates a majority of Canadian teachers are starting to make fuller use of digital technologies in the classroom, many still feel uneasy and ill-prepared to work with students who have grown up with these technologies (Lotherington et al., 2016). Research suggests experienced teachers-who are often assumed to be less tech- nologically adept-may be actually more likely to introduce digital technologies into the classroom, possibly because they are not as concerned about classroom management. They are more willing and better equiped to take risks (Johnson et al., 2016; Johnson, personal communication, 2018). With so much to learn about curriculum, pedagogy, and how to meet the needs of a diverse student population, it is understandable that teacher candidates new to the field might not consider video production a priority. They are also unlikely to experience video making in their teacher education courses or during practicum experiences in the schools. Research confirms teacher education programs are not providing all pre-service teachers with relevant opportunities to learn in technology rich, collaborative environments, and practicum may similarly offer relatively few tech supports for candidates (Brown, 2017; Lotherington et al., 2016). Faculty members who teach in teacher education programs are often, themselves, ill-prepared to integrate digital technologies into teaching and learning. In short, Brown suggests teacher education programs are struggling to keep up with societal needs.

At the same time, even very young children are discovering the power of video to engage and communicate meanings beyond what print text allows. They create and share songs, stories, and drawings privately and with online audiences (Hobbs, 2017; Lange, 2014; Vasquez \& Branigan Felderman, 2013). They take photos and make videos as a form of play (Lange, 2014; Wohlwend, 2013). Although media production is mandated in provincial curricula across Canada (Media Smarts, 2018), and students find it highly motivating (Miller, 2010; Mills, 2010; Spires, Hervey, Morris, \& Stelpflug, 2012), few studies have been conducted on the use of video production in elementary teacher education programs. This may be due to the fact that video has not been part of the elementary school learning experience until recently, as technologies have become more widely available and easier to use. This research therefore inquires into how teacher candidates (and in-service teachers) can be supported in their efforts to engage curriculum expectations, diverse identities, and critical perspectives through the creation and sharing of digital content using video technologies. This is about much more than acquiring technological expertise.

\section{Background to the Study}

My previous collaborative research conducted with three YouTubers-Kayf Abdulqadir, Fartousa Siyad, and Hodan Hujaleh-provided the impetus for the current study (Watt, Abdulqadir, Hujaleh et al., 2019; Watt, Abdulqadir, Siyad et al., 2019). That project inquires into the content of their videos, their media making processes, and how their work influenced their sense of identity as media activists from a community at risk of marginalization. Their videos powerfully speak back to dominant representations of Somali and Muslim women 
in the mainstream mass media (Watt, 2011a, 2011b, 2012). They are the first females in the Somali diaspora, and among the first Muslim woman, to create and share comedic content online, based on their lived experiences as racialized, Somali-Canadian, Muslim, female youth. Over the course of our collaboration I followed Kayf, Fartousa and Hodan around; listened to stories of their high schooling experiences and growing up in Ontario; discussed their videos and the production process; and co-produced a documentary to bring their work to educators and community audiences. I witnessed their growing awareness of themselves as media activists making a difference in the world. During this time, I was also inspired by the work of educators who create opportunities for youth to make videos to inquire into their own lived experience and promote social justice and intercultural understanding (e.g., Goodman, 2003, 2018; Ratner \& Friesem, 2018). Since video technologies have become widely available, relatively inexpensive, and increasingly easy to use, it is long past time that all students experience the transformative potential of meaning making and sharing with this medium.

Teacher education programs are potentially important sites to bring about educational reform. New teachers are exposed to research, theory, and pedagogies in their courses. Even if practicum experiences don't always mirror the most recent innovations, it is hoped recent graduates will be better able to negotiate these complex challenges. I have led video making workshops with numerous students in our teacher education program, both with my own students and at the request of other professors. However, my own areas of expertise is in literacies and curriculum studies, not digital technologies. Could a professor without a background in video production help student teachers learn to make videos? My work with three YouTubers convinced me of the importance of initiating video workshops with teacher candidates. I learned valuable technical skills working with Kayf, Fartousa, and Hodan. Much more importantly, they taught me new ways to approach teaching and learning in the digital age. As YouTubers, they understand the importance of collaboration, distributed knowledge, learning in real-time, persistence, asking for help when you need it, and a willingness to take risks.

My first effort to have student teachers make videos to engage curriculum and critical perspectives was four years ago in a course on the social contexts of schooling, with teacher candidates at the primary grade ( $\mathrm{K}$ to 3 ) level. This was an opportunity to test out my ideas on how to introduce teacher candidates to video production as a critical digital literacy practice. During the term we took up a range of social justice issues, including how to negotiate homophobia, racisms, sexism, inequality and priviledge; culturally appropriate pedagogies; issues around representation; and the consequences of absence in the curriculum. Course content provided students with a number of critical lenses through which to consider curriculum. For the final assignment, teacher candidates were asked to create an integrated unit plan in their subject area specializations that involved primary grade students making videos. The class worked in collaborative teams of three or four, and in spite of initial anxieties, together we negotiated technical, curricular, critical, and pedagogical challenges. The videos and instructional plans were inspiring. This is a sampling of the comments teacher candidates made on an anonymous questionnaire:

- We had a lot of fun doing this, and that's what we want for students.

- It's much simpler to make a video than people think.

- Kids who aren't strong writers can express themselves by making a video.

- You can get parents involved with a project like this.

- I can't believe how empowering it felt to make a video. Kids will love this!

- Nobody is an expert....We are all learning all the time.

- We all expressed our unique perspectives in our videos.

The response from teacher candidates at the screening and sharing session was transformative for everyone in the room. Student teachers were deeply inspired by their videos, and by the creative, critical, collaborative, and curricular possibilities offered by multimodal meaning making. It was clear that learning processes involved in video making were unique. Most students articulated the intention to make videos with their own primary students in the future. At this point, it was obvious that video production was worth pursuing with other teacher candidates, especially since few professors involved in teacher education were doing it.

\section{The Research Context}

This inquiry involves 40 pre-service elementary teachers in an integrated Language Arts/Arts course taught by the researcher, in a two-year teacher education program, at a large Canadian university. This small sample size and the fact that research was conducted in my own classroom might be considered limitations. However, it was important to work with students in depth for the duration of one semester to integrate critical video making into existing required course content. It would have been difficult for another professor to dedicate so much class time for research purposes as I would essentially have had to teach their course.

The elementary Language Arts/Arts course at my insitution prepares candidates to teach the four strands of the Ontario Language Arts Curriculum (Ontario Ministry of Education, 2006) at the Grade 4 to 6 level. These strands include reading, writing, oral communication, and media literacy. The Arts (Ontario Ministry of Educa- 
tion, 2009a) components integrated into the course are: dance, drama, fine arts, and music. It is taught from multiliteracies perspectives, with an emphais on the role of student backgrounds and identities in the development of literacy. Classes took place over one semester, meeting for twelve, three-hour sessions. Teacher candidates were in the second semester of a four semester certification program. This was the only literacy course they had taken so far in their program, and they would complete a second course at the primary (grades 1 to 3 ) level in year two. Student teachers could opt to take the one available stand-alone technology course during their final semester in the program. They had no other technology experiences in any of their course work up until this point. Two research questions guide this inquiry:

RQ1: How can video production be integrated into elementary teacher education to engage curriculum, diverse student identities, and critical perspectives?

RQ2: What insights can be gained into how to prepare pre-service teachers to navigate the 21st century classroom in relation to critical digital literacies?

The primary task involved teacher candidates collaborating in teams of three or four to design a multimodal instructional plan to engage cross-curricular expectations (in Language Arts, The Arts, and optionally in other curriculum areas), diverse student identites, and/or critical perspectives. The plan had to be designed as a teacher resource for other educators and posted to the course Wikispace in order to expand the audience for their unit plan beyond the professor. The content of the instructional unit was open-ended to permit students to choose areas of personal interest, and it had to involve students making videos. Each team was asked to produce a short mentor video they could share with their students as exemplars. The mentor videos were screened in class when students shared their instructional plans. Although all teacher candidates indicated they were active on various social media, only two had ever produced a video and shared it online (in a non-educational context), before doing this assignment.

\section{Data Collection and Analysis}

Visual ethnographic methods are used to collect data and respond to the research questions (Denzin \& Lincoln, 2011; Pink, 2007; Rose, 2012), since the teacherproduced videos are a central component of this study. As Pink points out, visual studies usually also incorporate traditional data sources, which is the case with this project. The final product and processes involved in making the videos are inextricably tied up with teacher candidate knowledge, identity, lived experience, and assumptions about teaching and learning literacies. Visual ethnography is therefore appropriate to understand their assumptions and changing conceptions of literacies.
In addition to the student mentor videos, a number of documents were collected and analyzed. These include the multimodal instructional plans created by teacher candidates and a reflective essay to justify the plan, analyze the collaborative video making process, and outline perecived challenges and possiblities of multimodal curriculum design with video. Participants also completed two anonymous questionnaires-one at the beginning of the video workshop and the other on the day the instructional plans were handed in. These were designed primarily to capture understandings of literacy, past experience with video making, and attitudes towards making videos with students before and after the workshops. The researcher and two doctoral candidate research assistants also took photographs and recorded field notes during the video production workshop. One focus group session was held after the end of the term, which was video recorded and transcribed. Participants were asked about their experiences completing the video and the multimodal instructional plan, as well as about their understandings of literacy.

Qualitative data analysis and writing were ongoing before, during, and after the course. Content analysis was conducted on the mentor videos to look for themes, critical perspectives, curriculum connections, and technical aspects. The videos, instructional plans, and reflective essays were independently coded by the researcher and two graduate student research assistants, for emergent themes related to the research questions. We were particularly interested in identifying language and themes related to the process of video making, critical perspectives, and literacies. Interpretation considers evidence from these numerous sources in relation to a New Literacies theoretical and pedagogical framework. The researcher did not know who had agreed to participate in the study, and no data analysis was conducted until final marks were submitted after the course. The video workshop process is transferable to other contexts, but results cannont be generalized based on one example. Tri-council ethics approval involving human subjects was granted from the researcher's university.

\section{The Multimodal Curriculum Design Process}

A number of experiences during the semester lead up to completion of this final assignment, in which teacher candidates were expected to apply theory and pedagogies they had learned during the course. The sequence of activities was designed to increase knowledge and understanding of curriculum content, in addition to theory and pedagogies related to both traditional print literacies and New Literacies. The Arts component is also treated as an important form of meaning-making, or literacy. Working with an understanding of Arts practices as literacy reinforces an expansive notion of literacies, and helps students to understand the concept of multimodality. Teacher candidates are exposed to print and New Literacies simultaneously and thus experience how 
they are not separate, but interrelated and dependent upon one another. Evidence from their multimodal instructional plans suggests a strong appreciation of the synergy that emerges when print and digital texts are integrated throughout the curriculum design process.

Early in the term, student teachers are introduced to the content of Language Arts (Ontario Ministry of Education, 2006) and The Arts (Ontario Ministry of Education, 2009a) curricula, as well as to historic and current understandings of literacies teaching and learning. Critical literacies follow soon after, to underline their significance. It is stressed that teaching children how to read and write is, of course, central to their classroom practice. However, they should never lose sight of the fact that it is what students do with literacy that is most important, even at the elementary school level (Willinsky, 2001).

To get teacher candidates thinking about how critical perspectives may be enacted through the use of video technologies, Kayf and Fartousa are invited as guest speakers. They share their YouTube videos and lived experiences as racialized youth from a community at risk of marginalization. After screening their work, they talk about how their videos are inspired by their family experiences and cultural background as SomaliCanadians. They also discuss their experience of absence in the Ontario Curriculum, and how they had to negotiate stereotypical representations of Muslim women in the mass media as high school students in the years following 9/11. Through the use of humor-both in person and in their videos-Kayf and Fartousa open up critical conversations in a less threatening way. By laughing at themselves, they make others feel at ease, which leads to difficult conversations around difference.

This guest speaker session serves a number of purposes: 1) teacher candidates have an opportunity to meet and talk with racialized, Muslim female youth, who, for virutally all members of the class, are from a different religious and cultural background; 2) having Somali-Canadian, Muslim females talking about making videos instead of being the subject of media portrayals, disrupts power relations; 3) personal narratives of the potential transformative power of representing oneself through making and sharing YouTube videos legitimizes New Literacies practices children and youth are involved in outside the classroom and highlights their significance; and 4) student teachers become curious about how video production might fit into their own school contexts. In other words, this session performs video making and sharing as critical digital literacy practice. By being part of this face-to-face conversation on YouTube videos, teacher candidates are invited to participate in a meaningful conversation on difference. Screening and responding to videos is an engaging way to involve students in critical reflection and discussion on difficult topics.

The final assignment is introduced the following week, mid-way through the semester. Teacher candidates then participate in a three-hour video production workshop as preparation for completion of the mul- timodal instructional plan. Students complete a short questionnaire to identify their previous experience with, and attitudes towards, video production. A short reading introducing student filmmaking (Hutchison, 2012) and simple video making resources are posted to the class Wikispace before this session as resources for anyone interested (e.g., shot sheets, blank storyboards, a chart with steps in the video making process, cross-curricular suggestions for video projects, and ideas for different approaches to representation such as puppets). Students are asked to form groups of 3 or 4 before the workshop. One member of each team must have a device with a camera. All of the videos end up being shot on mobile phones.

\section{The Video Production Workshop}

To set the stage on the day of the workshop, the class begins by having teacher candidates respond to the following question: What do you consider to be the benefits and challenges of having elementary students make videos in the classroom? The answers are posted anonymously on a screen at the front of the class using Padlet, an online bulletin board. The responses appear in Table 1.

Over the past three years, I have asked the same question to more than 500 teacher candidates at the beginning of video production workshops, and the pattern of answers has been similar for each group. There are generally more concerns than posssible benefits, suggesting resistance or lack of awareness about the potential of video. Before teachers have the experience of making a video, themselves, it's potential for multimodal meaning making tends to be vastly underappreciated. Most teacher candidates have had no experience with video production during their own schooling.

My research team and I then briefly review steps in the video making process, offer basic tips such as the importance of paying attention to sound quality, and provide storyboards. Students are prompted to plan, shoot, and publish a 30 second one-shot video, to be screened during the last 20 minutes of class. They are expected to create a student mentor video that could be shown to their elementary students as an exemplar (as part of their instructional unit). In terms of subject matter, groups choose a topic from any curricular area, but there must be strong links to the Language Arts Curriculum, with connections to The Arts. At this point, teacher candidates are also encouraged to think about how they could make their video critical and we discuss some examples.

Editing is not required, but most groups choose to undertake simple editing. Kayf, Fartousa and two graduate students are on hand to help out with any technical or creative issues that arise. We purposely avoid explicit teaching of technical skills. Students are expected to learn in their collaborative groups and get help from our team, if needed. This makes them feel support is available, but they soon realize they are capable of cop- 
Table 1. Challenges and benefits of making videos in the elementary classroom.

\section{Challenges of having elementary students make videos in the classroom}

- I don't know anything about video or editing.

- I have never made a video before.

- There are so many other more important things we need to learn in our teacher education program.

- Access to technology is limited in schools. Is it expensive?

- It takes too much class time and effort for students to make a polished video.

- Privacy and safety issues with kids filming one another and sharing online.

- Video may be too distracting and kids might fool around too much. It might be hard to manage.

- Need for parental consent.

- It's too risky.

- I would only do it after I had the proper training and ongoing support.

- We already have so many responsiblities. It's too much.

- I haven't seen any teachers in my school doing this. Is it even allowed?

- There could be tech failures and I wouldn't know what to do.

- I worry kids could damage the equipment.

- How would you evaluate a video?

- Is it in the curriculum?

- Kids already spend too much time on screens.

- Students might be overstimulated.

- Some kids might not want to be filmed.

\section{Benefits of having elementary students make videos in the classroom}

- It engages many types of learners.

- Students who struggle with traditional literacies might excel making a video.

- We need to keep up with new technologies.

- Kids would find it fun.

- It encourages creativity.

- Videos could be shared with many audiences, including families and other classes.

- It is another way to demonstrate learning.

- It would be good to use with students who are anxious about public speaking.

- It's a platform where students could raise important issues.

- Kids need to learn to use different technologies.

ing within their teams. Seldom do teacher candidates ask for assistance at this stage. Once they are convinced of the value of video making as a significant literacy practice they can pursue other opportunities to develop technical expertise if they are interested, but this is not necessary.

As the professor, it is important to decenter as "knower" to disrupt the notion that a teacher must know more than students, and to model a collaborative approach to teaching and learning. Everyone is expected to learn with, and from, one another and to access readily available online resources if needed. By the end of this session teacher candidates have a better appreciation of the concept of distributed expertise and the benefits of sharing knowledge, skills, and power with students in the digital classroom. Along with experiencing the power of collaboration and learning-as-you-go, this is one of the main goals of the workshop. The de-emphasis on technological skills and time pressure create the conditions in which collaboration is necessary to get their video ready in time for screening. Some students will have some technical expertise, others will write the script, while others will be willing to act in the video. I first witnessed this approach to video making during a workshop for Israeli and Palestinian youth, led by Dr. Yonty Friesem at the Summer Institute in Digital Literacy at the University of Rhode Island. Team members had to rely on one another to get their videos made in time for public screening. Rather than focus on technological skills, the emphasis is on teamwork and comprehensible content. There have only been two groups over the years who did not meet the screening deadline at the end of a workshop. This was because they had members with video experience and their projects became too complex to finish in the time allotted, so their screening was delayed until the following class.

Some of the student teachers were anxious at the start of the workshop. Most had never made a video before and imagined it to be difficult. After instructions were given, everyone got to work quickly and focused intensely on the task. There was soon a high level of engagement, with much talk and laughter in the classroom and hallway where students were working. Some groups used puppets from the resource center and others acted in their videos. Once everything was posted to 
YouTube it was time for the screening. Teams were visibly relieved they were able to meet the deadline. They were proud and many were surprised to be able to produce a video to share with classmates. Each group introduced and screened their work, and the class response was overwhelmingly positive. Everyone seemed to feel the excitement and a sense of accomplishment. Teacher candidates are also surprised at how easy it is to make a video, which opens up thinking about what is possible with students.

\section{Results and Discussion}

\subsection{Elementary Pre-Service Teachers Make Videos: Attitudinal Shifts}

Survey responses on the pre-workshop questionnaire and interview data from the focus group session indicate that at first the majority of teacher candidates were positive, even if somewhat uncertain, about the value of making videos with elementary students. It may be that most thought this seemed a good pedagogical strategy, but they did not know what that might look like. They were concerned about a lack of technical skills, questioned the relevance of using student-made videos to engage curriculum expectations, and did not consider video making a practical classroom activity due to time constraints and technological requirements. Many also wondered if video production could be too distracting or difficult for students in the elementary grades.

This was the first time video had been introduced in their teacher education program, and none of the teacher candidates had seen student-produced videos during practicum or in their own schooling experiences. However, questionnaire data collected after the instructional plans were finished indicate that participation in the collaborative process of multimodal curriculum design led to postitive attitudinal changes. Table 2 provides a summary of this shift.

The most significant result according to the final questionnaire was that $100 \%$-all teacher candidates in the class-indicated they plan to have their future students make videos to engage curriculum and digital literacies.

Candidates were surprised making a video was much easier than they had anticipated, and most found it en- joyable and engaging. Student teacher reflections on the process from the focus group discussion suggest a high level of enthusiasm after the hands-on experience making videos themselves, followed by having to incorporate video making into an instructional plan:

I'm very inexperienced with video and technology. I find technology very daunting and I don't really like videos on my phone or anything like that. I don't know how to upload or edit them, so I really have no experience. This project stressed me out in the beginning because I didn't really know what we were going to have to do. When Diane mentioned video production, I was like, “Oh, my God!" [laughter], but it wasn't that hard after we did it. It was the collaborative part that made it work. You had support from your colleagues.

I was so impressed with how much everyone got out of making videos in this course.

You could see how excited many people were making their video. I would never have thought of bringing video into my teaching before this. It was such a new idea to me.

These comments coincide with our team's observations of teacher candidates during the video workshop. There was doubt at first, but by the time the videos were screened at the end of class, trepidation shifted to enthusiasm. Participants recognize video making is new in most classrooms and understand they are being initiated into a practice that has a great deal of potential.

After the workshop, student teachers view the technical aspects of video making as within their reach, and they recognize the benefits of collaboration on a technical task most assumed was beyond their level of knowledge and technical expertise. A number of students noted that they benefited not only from learning how to make and share a video with other members of their team, but also from viewing the videos other groups had created:

This experience made me more comfortable bringing video into the classroom. I think I was still a little tentative about the assignment after we were done. We weren't sure that we went into enough depth with the

Table 2. Teacher candidate attitudes to video production in the elementary classroom before and after designing a multimodal instructional plan.

\begin{tabular}{ll}
\hline $\begin{array}{l}\text { Before Completing the Video Workshop and } \\
\text { Multimodal Instructional Plan }\end{array}$ & $\begin{array}{l}\text { After Completing the Video Workshop and } \\
\text { Multimodal Instructional Plan }\end{array}$ \\
\hline $\begin{array}{l}73 \% \text { of teacher candidates did not feel confident integrating } \\
\text { video into instruction to engage curriculum and }\end{array}$ & $\begin{array}{l}93 \% \text { of teacher candidates felt confident integrating } \\
\text { video into instruction to engage curriculum and } \\
\text { critical perspectives. }\end{array}$ \\
\hline $\begin{array}{l}64 \% \text { believed students could benefit from making videos } \\
\text { in the classroom. }\end{array}$ & $\begin{array}{l}100 \% \text { believed students could benefit from making videos } \\
\text { in the classroom. }\end{array}$ \\
\hline
\end{tabular}


critical part. During the screening, when we saw what all the other groups had produced we got a much better idea of what it means to be critical and how we could bring that into the classroom using video. It was very helpful to watch other people's videos.

I got so many great ideas from watching the videos made by my classmates. I really want to get the kids to make a video on my next practicum placement.

It was so great to see so much engagement in our class. We aren't always that excited by what we do in teacher education. Even though students in our class didn't have much experience making videos, we forged ahead together. I think its important to take risks, ourselves, because we are asking kids to take risks. You don't always understand an assignment or a technology, but you have to struggle through it and I think this helps you grow.

Student teachers articulate the benefits of collaborating on a curriculum design project and of sharing work with other educators. With so many demands on teachers today-including the need to integrate digital technologies into the curriculum-collaboration on curriculum planning has become essential, and also enriching in terms of professional learning (Knobel \& Kalman, 2016). Unfortunately, although collaboration is often promoted in teacher education programs, these programs tend to require students to complete assignments independently for fear that grades may not accurately reflect individual achievement. This is one of of the issues we need to work through as educational paradigms shift. If collaboration is truly valued, how must assessment and evaluation transform?

\subsection{The Multimodal Curriculum Design Projects: Engaging Curriculum and Critical Digital Literacies}

In addition to a more "can-do" attitude regarding the technical aspects of video production, and a stronger understanding of the benefits of collaboration in the digital classroom, focus group data and content analysis of the instructional plans also indicate student teachers had a good grasp of how to use video making to integrate crosscurricular expectations and critical literacies into instruction. My research team analyzed the unit plans and accompanying student mentor videos the teams of teacher candidates completed collaboratively as the final assignment in the course. Content and themes were identified to look for evidence student teachers were able to apply new skills and understanding by integrating student video production into a unit of study in Language Arts (with the option of including other subject areas), to engage curriculum expectations and critical perspectives. We also sought evidence that understandings of literacy had expanded, which is discussed further below. In total, 10 assignments were analyzed. All groups successfully integrated traditional print and New Literacies perspectives into a Language Arts unit plan, and engaged curriculum expectations and critical perspectives.

Teacher candidates chose critical content they were familiar and/or comfortable with, with some groups going further than others. Students come to teacher education from various academic backgrounds, and those from disciplines more focused on critical perspectives found the task easier. A number of critical issues are taken up in the instructional plans, including environmental sustainability, identity and difference, intercultural understanding, and gender. In several of the unit plans, students deconstruct representations to identify who is portrayed and who is left out. After a unit of study, most of the videos involved students sharing their research, knowledge, understanding, and/or identities with audiences beyond the classroom to inform and to inspire change. For example, in one instructional plan students are asked to create a news broadcast to think critically about endangered animals and the impact humans have on their habitat and community. The unit plans describe the purpose and audience for the student videos:

Students will direct their videos to the school community and encourage their peers to make conscious choices when in a natural environment. The student's videos will capture the attention of their school community by using real-life facts on their chosen endangered animal and ways in which we can change our lifestyles to promote healthy habitats and communities.

Other topics taken up in the instructional plans include: an anti-bullying awareness campaign; creating nonstereotypical news stories; challenging gender stereotyping in advertisements for children's products; telling a fairy tale from a different perspective; writing a personal anthem based on student identities and interests; a novel study that focuses on critical thinking; creating a public service announcement on endangered animal species; and a critical approach to exploring identity through dance. Critical digital literacy practices offer opportunities for students to become designers of powerful texts (Kress, 2010). As Ávila and Zacher Pandya (2013) remind us, in the context of participatory culture (Burgess \& Green, 2009; Jenkins et al., 2006), they offer alternative methods of teaching and learning that potentially disrupt traditional banking systems of education (Freire, 2000).

Critical pedagogical strategies used in the unit plans include: discussion, writing tasks, reflection, questionning, deconstructing media representations, and producing digital/media messages. A number of the unit plans have students viewing and critiquing videos before they create their own. This is a key strategy, for students need experience analyzing how multimodal texts make meaning in order to produce digital texts that communicate effectively. Student teachers also built in opportuni- 
ties for critical feedback from various audiences during screenings of rough cut videos and during final screenings, which opens up additional spaces for critical conversations. One group explains:

Students will screen their videos in the library as part of a film festival. Classes will be invited to view student films at their individual tables and students will have the opportunity to explain their video, the production, and their critical examination of news stories.

Given their limited knowledge of video production at this point, most groups chose not to formally evaluate technical aspects of the student videos, but instead focused on effectiveness of communicating the message, organization, and evidence of knowledge and understanding of curriculum expectations. Of course, technical choices affect meaning making, but teachers recognized this would gradually become more sophisticated as they and their students gained more experience with video. Some of the unit plans also evaluate collaborative skills, which, again, illustrates the degree to which teacher candidates considered community building to be one of the most significant benefits of video production.

Following is a closer examination of three of the multimodal instructional plans. These were chosen to illustrate the broad range of cross-curricular topics and pedagogies taken up by teacher candidates. The first, designed for Grade 6, engages gender roles through a study of advertising directed at children. The authors demonstrate how video production can be used to engage crosscurricular expectations and critical perspectives. The second unit plan has Grade 4 students critically evaluate whose point of view is presented in a text and identify missing or alternative points of view, through rereadings of traditional fairy tales. The student mentor video represents the wolf's point of view in the story, The Three Little Pigs. In the third instructional plan, designed for Grade 5 , students take up a critical perspective on traditional dances from around the world. The focus on intercultural understanding opens up a space to bring diverse student identities and cultures into the classroom and is thus an important example of how video can engage multiliteracies perspectives.

\subsubsection{Example 1: Gender Roles and Stereotypes in} Advertisements for Children's Products

As one team notes in the introduction to their instructional plan, "video making is a wonderful way to integrate curriculum expectations." All groups successfully integrated Arts and Language Arts curriculum expectations into their plans. However, most went well beyond this basic requirement to include other curriculum areas such as Science, Social Studies, and Health. This unit on gender roles and stereotypes in advertisments for children's products integrates cross-curriculuar expectations while taking up critical perspectives on gender. Students at the
Grade 6 level can relate to the topic of gender roles and advertising, making this a developmentally-appropriate means to engage these key areas of critical literacy. The unit is summarized in the introduction:

During the unit students critically analyze the implications of gender roles and stereotypes. They begin by comparing two commercials advertising the same product, but each has a significantly different intended target audience, based on gender. The class analyzes and discusses how this product is presented differently to girls and boys. They will aquire a working understanding of how stereotypes about gender and gender roles impact the human development and self concept of others. They will also learn appropriate ways to deal with and modify these assumptions and stereotypes by creating their own media texts. Students work in teams to apply their understandings by designing and filming a commercial for the same product that is gender neutral.

The authors of the unit plan explain how it integrates cross-curricular expectations from Language Arts (reading, writing, and media literacy), The Arts (drama), and Health and Physical Education (human development and sexual health). They describe how it engages critical literacy skills to evaluate gender roles and stereotypes in advertising (although they do not critique binary gender identities), and that New Literacies are developed as students create videos to apply and then share their understandings.

The student mentor video depicts people playing with the product, which is a play dough. Only hands and arms are filmed, and subjects wear black, so no explicit allusions are made to gender. The use of a variety of colours also disrupts a particular colour being associated with being female or male, also opening a space for the existence of other gender identities (Figure 1). This contrasts with the two advertisements students critique together, which specifically target girls and boys using colour and themes. This student mentor video provides a comprehensible alternative to the product's stereotypical ads, scaffolding student learning.

In their reflective essay, these teacher candidates draw upon concepts taken up during the course in class activities and readings to justify their curriculum design choices. This is an opportunity to apply what they have been learning all semester. For example, they reference a number course readings related to literacies and equity, including Ontario Ministry of Education policy documents. This excerpt from the unit plan describes how power circulates in media representations, and explains how a child's gender identity is formed gradually, with media being an influential site:

Watching little girls play with dolls, and little boys play with trucks can have a huge impact on shaping the identity of a child. It could also be an issue when an in- 


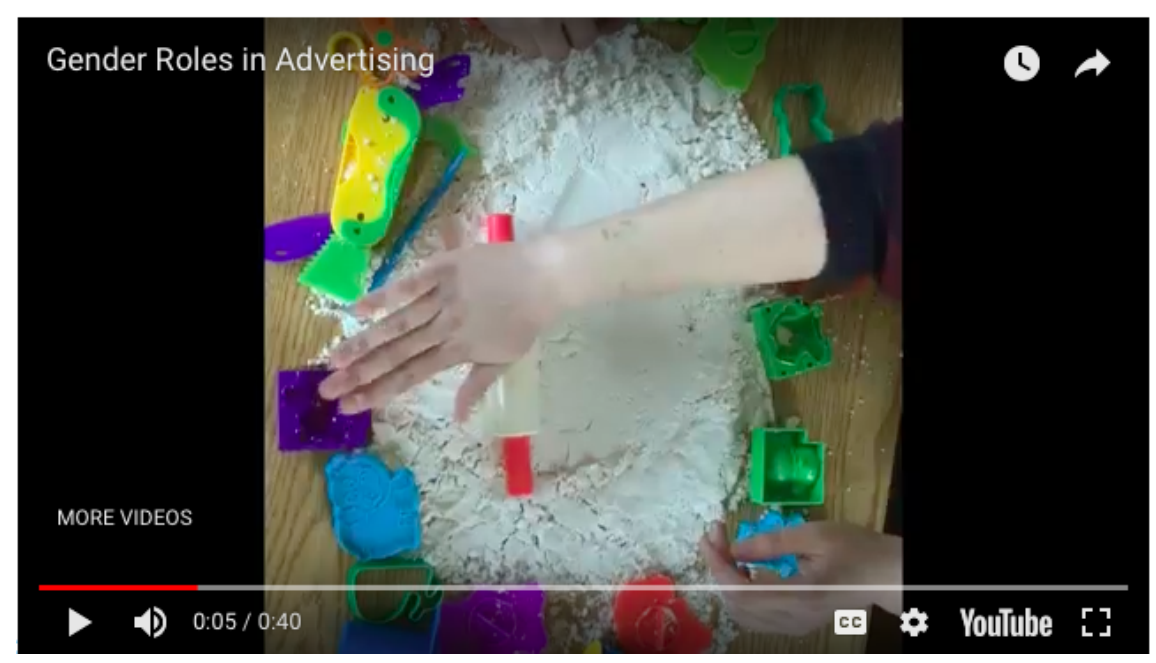

Figure 1. Student mentor video depicting neutral gender roles in advertising for children.

dividual child doesn't fit into the roles on offer in the media. This unit gives students the opportunity to critically analyze factors that may have shaped their own sense of identity.

This team also mentions the power of video making to encourage creativity and facilitate the learning process. They argue assignments that ask students to make videos to demonstrate understanding and share their perspectives are also likely to foster a love of learning given that many students find video enjoyable and motivating. The final student videos are assessed on curriculum and critical content as well as depth of understanding of stereotypical gender roles.

This multimodal instructional plan thus provides an example of how video production as a critical digital literacy practice can be integrated into the Grade 6 curriculum. With no previous experience or available exemplars, these teacher candidates engage the topic of gender stereotyping, and bring together numerous curricular areas of inquiry by focusing on critically reading and producing digital video advertisements.

\subsubsection{Example 2: A Fractured Fairy Tale: The Three Pigs and the Big Sick Wolf}

This second instructional plan for Grade 3 or 4 students contributes to understandings of how to engage critical literacy with younger children (Vasquez, 2013; Wohlwend, 2013). The unit invites students to reread traditional fairy tales from an alternative point of view. Fractured fairy tales are not new to the literacy field, but the practice of rereading is only one half of the critical literacy process. Students also need to be able to create their own meanings, which is where video production can be introduced. As the authors of this unit contend, "it is important for students to understand the various ways they can create meaning without pen and paper." Like other groups, the designers of this unit note:
Students will demonstrate their ability to express their thoughts and ideas in a new format. By using a multimedia platform and creating a short video, students will be involved in traditional print literacy practices before they even begin the filming process. They will complete lessons and activities that include brainstorming and planning; and rewriting scripts by modifying the plot, setting and/or characters. Students will critique and offer peer assessments of their classmates' videos and written work.

Again, video (Figure 2) greatly expands opportunities for sharing and critique, which makes it an appropritate medium to engage not only disciplinary knowledge, but critical digital literacies.

This group draws from Harste (2014) to emphasize the importance of transmediation in the classroom. They explain that "oving across sign systems (from language to art, for example) has been shown to generate new ideas and new insights" (p. 91). In the introduction to the unit, teacher candidates lay out that during this unit of study, through video production "students are able to portray a variety of emotions and sensations that would often be lacking in a written piece." They write that "by offering students the opportunity to express themselves using a variety of multimedia forms we are creating a dynamic and engaging learning space." Throughout the course the importance of student engagement was stressed, and based on their own experiences during the video production workshop, student teachers came to view video as a meaningful way to motivate and engage their students.

These teacher candidates go on to justify their curriculum design by emphasizing links between traditional print literacies, digital literacies, critical literacies, and transmediation:

Transmediation is an overarching feature of our lessons in which students listen, interpret, and perceive fairy tales in a certain manner and are asked to reimagine 


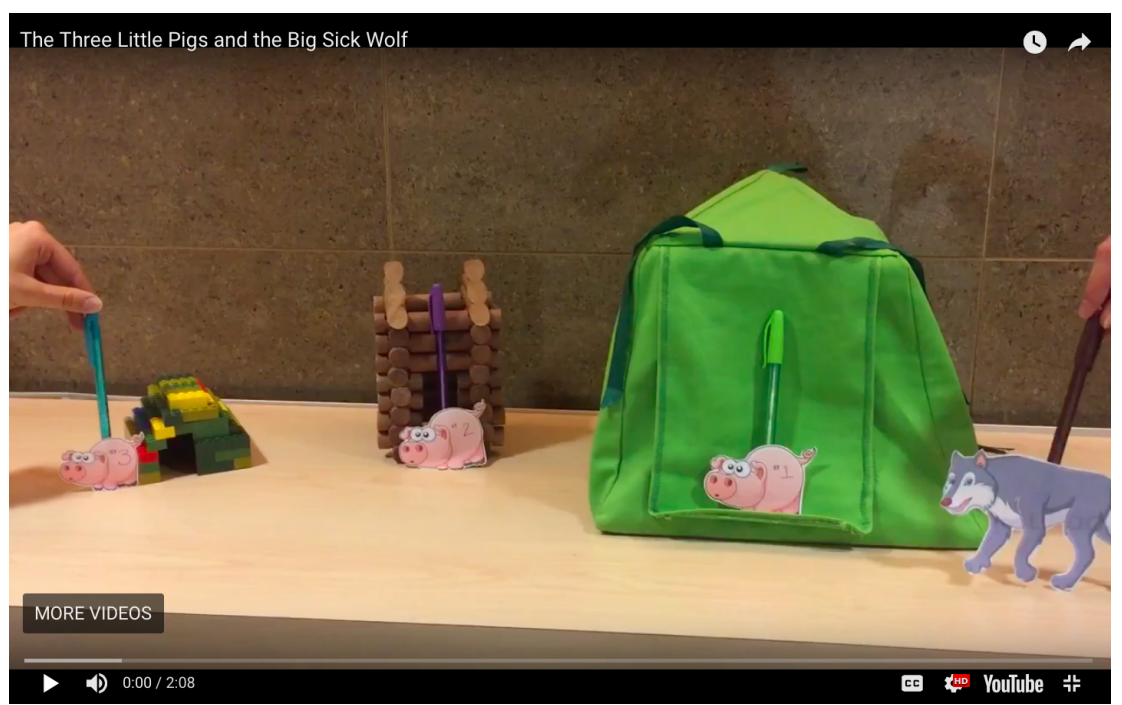

Figure 2. Screenshot of student mentor video: The dramatization of Three Little Pigs from the wolf's perspective, using stick puppets.

this tale from another point of view....They are then asked to express it using digital video technology.

This team also articulates the need to bring critical literacy into the elementary curriculum to help students identify, reflect on, and analyze power relationships in texts. Their focus on how print and digital stories can be interpreted from different perspectives is an important component of a strong critical digital literacy practice.

\subsubsection{Example 3: A Critical Approach to Inquiring into} Identity Through Dance

This group inquires into identities and cultures through dance during the video production workshop (Figure 3). Their student mentor video consists of a series of short dance clips found online that represent their own cultural backgrounds. To make their video, they taught themselves how to import short clips from YouTube into an iMovie template. During the screening, it was inspiring to hear their account of learning about one another during the process of making their video in the workshop. These pre-service teachers explained how the curation and sharing of cultural texts to include in their short student mentor video lead to better understanding of one another's identities and cultures. They were also surprised at how the act of collaborating on a short video helped them get to know one another, and now viewed video making a powerful community-building strategy. Multiliteracies theory stresses the importance of community and bringing student identities into the curriculum to promote literacy development. If learners do not feel like valued members of the class and/or do not see themselves represented in the curriculum, they risk marginalization (Dei et al., 2000; Watt, 2011a, 2011b).

This team's multimodal instructional plan mirrors their lived intercultural experiences during the initial video workshop. In the introduction, the authors explain

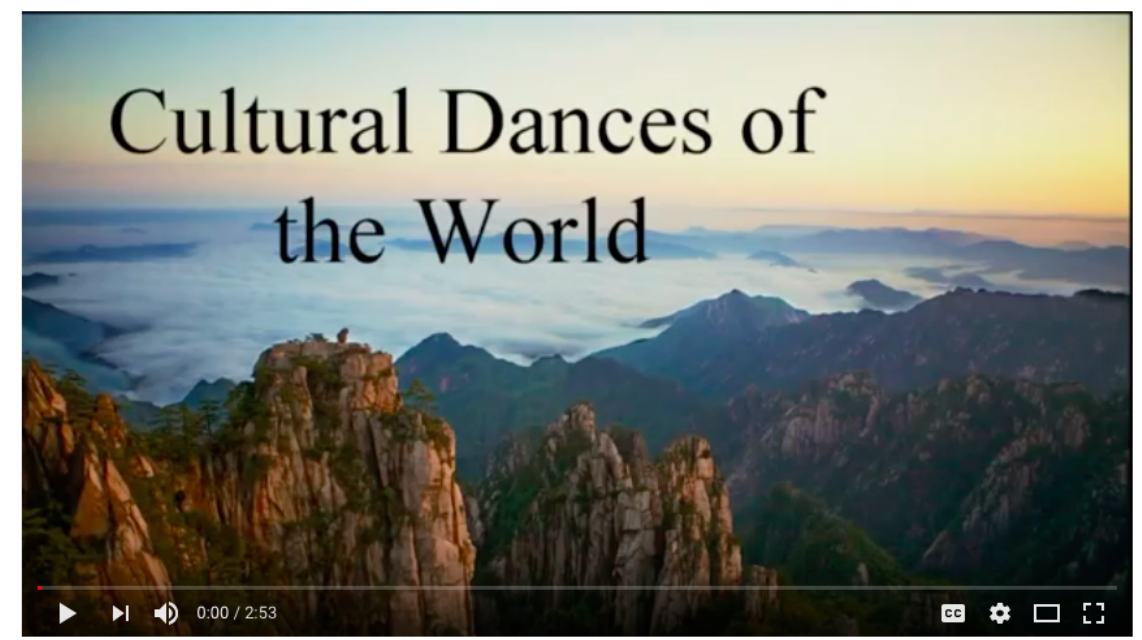

Figure 3. Screen shot of student mentor video on critically inquiring into identity and culture through dance. 
their unit promotes critical literacy by encouraging students to ask questions and reflect as they create their own video and read the videos that other students make. They underline what they consider most significant in their Language Arts/Arts unit of study:

This dance activity promotes diversity and acceptance among students and awareness of other cultures. Students are able to learn through collaboration with peers.

One of the activities in the unit involves a critical discussion of the issue of representation in the media and whose voices are excluded. The main assignment requires students to work in groups to create a dance video that represents their own families and cultural backgrounds. Students use YouTube as a resource and must include a voice over that explains meanings represented in the dances. Through this process, it is hoped students will challenge assumptions by learning more about themselves and others. The unit integrates expectations from the dance strand of The Arts Curriculum (Ontario Ministry of Education, 2009a), which madates that students at the Grade 5 level demonstrate and understanding of a variety of dance forms, traditions, and styles from past and present, and their sociocultural and historical contexts. In addition, all four strands of the Language Arts Curriculum (2006) are engaged in this unit, including oral communication, reading, writing, and media literacy.

This example highlights that there is much more going on during the three-hour video production workshop than the acquisition of technological expertise. Here, teacher candidates focus on critical content and curriculum expectations from The Arts and Language Arts. The process of making a video collaboratively becomes the site where students (and teacher candidates) actively engage with curriculum, critical literacy, and colleagues to co-construct new understandings of identities and cultures. As this unit plan demonstrates, the multidimensional aspect of video production as both process and product opens up new venues for teaching and learning in the digital classroom.

\subsection{Expanded Understandings of Literacy}

There is also evidence to suggest that participating in a simple hands-on video production workshop followed by a curriculum assignment requiring the integration of video production into a Language Arts instructional plan, expands teacher candidates' understandings of what counts as literacy. In their unit plans and reflective essays, student teachers integrate literacies theory and pedagogies introduced during the term. The instructional plans as a whole demonstrate that participants' understanding of video as a different form of meaning making was strong. Although not every student teacher explicitly mentions multimodality as an key feature of meaning making with digital video, it was often implied in the unit plans, the reflective essays, the focus group session, and the questionnaire responses. Teacher candidates made the following insightful observations about the significance of video making:

Constructing meaning with video is unique because it's your whole body. You experience it through all of your senses when making it, but when screening it, too! To watch the images and see someone in action, the movement, it adds another layer of meaning. I think a lot of kids at the elementary level have an easier time expressing themselves through acting or moving. Some kids can't write down an idea on paper, but they could act it out. Some kids would be more comfortable making a video over writing a poem.

In this course I have come to appreciate digital literacy more than I did before. I now appreciate how much video can add to the Language Curriculum. There is so much you can do with it.

Even with getting kids to make identity texts...it's such an important way for people to be able to express themselves.

I think about literacy differently now. Video can help me communicate with the world. It is so complex. You have to think about movement, the use of colour, body positions. It's all those little things that you might not think about reading a book or a print text. Video lets you share experience differently.

With our world immersed in social media platforms such as Facebook and Instagram, our youth grow up in a digital world that they need to understand and be able to apply to their everyday ives....Youth and children can use these to find a voice for themselves, so educating students on the benefits and proper use of these technologies is important.... Incorporating video production into our teaching allows for students to express themselves in ways that pen and paper simply cannot. This is a very different, yet interesting and fun way for students to learn.

I see the importance of bringing in video now. We didn't do much media literacy on my practicum. I am much more excited about taking this into the classroom and helping young kids learn to use video technology. I have a degree in English, so have always been into books. I'm very old fashioned, but now I'm seeing the benefits of incorporating new technologies and new media into the classroom.

These teacher candidates appreciate the affordances of video, and recognize meaning making using this technology as complex. They see that video (and other digital technologies) does not replace traditional print literacies, but reinforces and extends them. Even an English 
specialist who loves books and admits to being "very old fashioned" concludes that video should not be ignored by teachers. Many make connections between the ubiquitous use of digital technologies outside the classroom and what is happening, or not happening, in our elementary schools. Conceptions of literacy greatly expanded when these teacher candidates had the opportunity to experience the affordances of video production first hand and then design their own multimodal instructional plans. Teacher candidates no longer viewed traditional print literacies and New Literacies as separate. In all of the multimodal unit plans, there was strong evidence they understood the potential of combining traditional print literacies with New Literacies, through preproduction activities such as researching, discussion, storyboarding, script writing, and planning. They also suggested opportunities to engage traditional forms of literacy post-production through follow-up activities, including oral and written feedback and critique to other groups, reflective writing, and discussion sessions with various audiences. The possibilities are endless.

Every group in this study went beyond what was expected with this assignment, because they found making videos engaging and relevant for their students. A number reported this as their favourite assignment in the program. They were impressed by how making videos fosters collaborative skills and a sense of community. Having students make videos is also a powerful way to engage cross-curricular expectations. Significantly, all participants stated that they plan to have future elementary students make their own videos.

\section{Implications for Teacher Education}

Returning to the research question on how video production can be integrated into elementary teacher education to engage curriculum, diverse student identities, and critical perspectives, the short answer is that it may be easier than one might expect. As this research demonstrates, a single collaborative hands-on experience working with video technology followed by an opportunity to integrate that technology into an instructional plan, led to significant changes in teacher candidates' attitudes and perspectives on literacies, curriculum integration, and the importance of new communication technologies. This one experience with video making and curriculum design convinced teacher candidates of the significance of video to promote traditional and new forms of learning, even with students in the elementary grades. They left the course more confident about introducing video production into the classroom by rethinking their own assumptions about teaching, learning, student-teacher roles, and expertise in a participatory culture. By grappling, themselves, with the technical challenges and curricular possibilities related to video production, they become convinced of its unique qualities and value. They experienced the potential of expansive and unique forms of meaning making now available to students through the combination of traditional print literacies, critical perspectives, and digital technologies.

With regards to how to prepare pre-service teachers to navigate the 21st century classroom in relation to critical digital literacies, this study demonstrates that it begins with teacher educators and their willingness to take risks. Like student teachers, they also need to be convinced that advanced technological expertise is no longer required to introduce video production (and other digital technologies) into their courses. It is much more important to create space in a given course for teacher candidates to inquire into how video production represents a different way of learning that engages new forms of knowledge construction essential for critical literacy in the digital age. Teacher educators need to decenter their own authority to disrupt traditional student-teacher roles, which are no longer appropriate in the information age. Teacher education programs should model collaboration and power-sharing between teachers and students, where everyone learns from everyone (Hobbs \& Coiro, 2016). This implies that teacher educators acknowledge that given rapid and continuous technological advances, they are also always learners.

\section{Recommendations}

This inquiry demonstrates that teacher candidates' learning in this course was transformational. Integrating video production into elementary teacher education not only greatly impacted teacher candidates' understandings of what counts as literacy. When integrated into the curriculum design process, it is an effective means to engage cross-curricular content, diverse student identities, and critical perspectives. The multidimensional attibutes of digital video make it the ideal technology to introduce into teacher education programs to help pre-service teachers gain the perspectives, dispositions, and confidence they need to navigate the 21st century classroom. Most importantly, video production facilitates the development of critical digital literacies, which are essential for life, learning, and citizenship today.

A number of observations and recommendations emerge from these findings, which may inform teacher education programs as well as professional learning for in-service teachers:

1. Video making promotes multidimensional learning. It can be the focal point of student inquiry. During the process of making a video students develop valuable collaborative and community-building skills and dispositions that are transferable to other contexts. In addition, print literacies and oral communication skills are engaged and reinforced, promoting these all-important traditional literacies alongside digital literacies. Videos also become products that can be shared face-to-face or online, opening up access to broader audiences and feedback. Having teacher candidates make their own videos in teams exposes them to the many the affordances of video production. 
2. Making and sharing a video is not difficult. Although many educators assume video is difficult to learn, time-consuming, and too challenging for elementary students, this research and my work with numerous teachers (Canadian Institute for Digital Literacies Learning, 2017; Critical Digital Literacy Project, 2018), students, and teacher candidates dispells this notion. More advanced technological learning can come later, if and when it is required. The point is to be willing to get started by learning with and from colleagues and students, for we learn by doing (Knobel \& Kalman, 2016).

Teacher educators do not need to be technology specialists. In fact, it is good practice to decenter one's authority, share power with teacher candidates, and model risk-taking. New teachers need to experience what this looks and feels like, so they will be more likely to take similar risks in their own classrooms.

This research demonstrates making a single video collaboratively is enough to instill confidence, and because it is enjoyable to make and see the final product, people get hooked and want to do more. It is enough to create a space in the classroom that invites experimentation, while providing whatever support one has access to, such as articles, website resources, YouTube tutorials, and/or youth media makers or colleagues willing to share their work and offer support. Once teacher candidates have made a video, follow up by having them integrate video production into a curriculum design project related to course content. This is where much of the deep learning occurs.

3. The experience of video making expands teacher candidates' understanding of of what counts as literacy. Research has shown that teacher attitudes are key to change in the classroom. The teacher candidates in this study no longer viewed collaborative multimodal meaning making with video technologies as optional. After completing this project, they understood the uniqueness of multimodal meaning making as complex learning and powerful communication. They also considered digital literacies to be as important as traditional print literacies.

4. There is no need to drastically change what you are already doing. The sequence of activities teacher candidates completed in order to create their multimodal instructional plans was not novel or complicated. The only new element was the video making. This means that any teacher educator could potentially make this one addition to their course to open up vast new possibilities for teaching and learning.

5. Teacher candidates should be invited to take the lead. By the end of the semester-even though they had never done it before and had few exemplars to followall of the participants in this study were able to make and share a video, and then meaningfully integrate student video making into a cross-curricular instructional plan to engage curriculum expectations and critical perspectives. Positioning pre-service teachers as knowledge generators (Simon, 2013) and classroom innovators may be key to their development as critical digital literacy practition- ers. In a course on integrating technology across the curriculum, I ask teacher candidates to work in groups to develop and lead a workshop on integrating digital technologies for future colleagues they will work with after they are hired on as certified teachers. They either draw upon current skills and knowledge, or they may choose to research a technology they are interested in for a particular curricular purpose. Through this activity they experience what learning looks like in the information age where expertise is one click away. By teaching colleagues, candidates gain confidence as they develop a DIY ethic (Knobel \& Lankshear, 2010; Ratto \& Boler, 2014), which is needed to navigate our networked classrooms and societies.

6. Video making is an exemplary critical digital litearcy practice. The teacher candidates in this study successfully designed instructional plans that engaged critical perspectives in the elementary classroom. Making and sharing videos potentially lends itself to classroom inquiry projects that focus on important social justice issues of interest to students when students are simultaneously introduced to critical perspectives. Video also expands possibilities for student voice to reach communities beyond the classroom and the school, potentially making learning more relevant and authentic. Students find sharing their identities, lived experiences, and perspectives with others through video production represents engaging and empowering learning.

\section{Scholarly Significance}

This research contributes to New Literacies theory and practice, curriculum studies, and teacher education by offering insights into how to shift teachers' understandings of literacies and critical perspectives through the integration of video production into the curriculum. In broad terms, this investigation contributes to understandings of what knowledge and skills are required to thrive in an interconnected, evolving global landscape. Research, policy, and practice must take into account the transformed nature of literacies in the digital age. The process of teaching and learning New Literacies is new to many educators and involves more than just access to technology. Curriculum, pedagogy, and teacher education must be reimagined. This research takes up this pressing challenge. As Williamson (2013) reminds us, "[a] paradox of teacher education is that we must prepare teachers for the schools we have while at the same time we must prepare them for the schools we want" (p. 2). In our diverse, networked societies, new technologies are introduced continously, and elementary school educators need to contend with this shifting reality (Leu et al., 2015). Our schools must adapt to continuous change, and teacher education has an important role to play in this transformation (Watt, 2016a). The integration of video production as a critical digital litearcy practice into our teacher education programs may represent a simple, but effective means to negotiate many of these current challenges. 


\section{Acknowledgments}

Funding for this research has been provided by the Social Sciences and Humanities Research Council of Canada through an Insight Development Grant. Thank you to my research team for their valuable contributions to this project: Jamilee Baroud and Genevieve Cloutier (Doctoral Candidates at the University of Ottawa); Fartousa Siyad, Kayf Abdulqadir, and Hodan Hujaleh (YouTubers and Youth Media Activists).

\section{Conflict of Interests}

The author declares no conflict of interests.

\section{References}

Ávila, J., \& Zacher Pandya, J. (2013). Traveling, textual authority, and transformation: An introduction to critical digital literacies. In J. Ávila \& J. Zacher Pandya (Eds.), Critical digital literacies as social praxis: Intersections and challenges (pp. 1-12). New York, NY: Peter Lang.

Bailey, N. (2006). Designing social futures: Adolescent literacy in and for new times (Unpublished doctoral dissertation). Buffalo State University of New York, New York, NY.

Brown, E. (2017). Exploring the design of technology enabled learning experiences in teacher education that translate into classroom practice (Unpublished doctoral dissertation). University of Calgary, Calgary, Canada.

Burgess, J., \& Green, J. (2009). YouTube: Online video and participatory culture. Cambridge: Polity Press.

Canadian Institute for Digital Literacies Learning. (2017). Canadian institute for digital literacies learning. Retrieved from http://www.digitalliteracies.ca/ welcome-2

Common Sense Education. (2018). Educator resources for digital literacy. Retrieved from https://www. commonsense.org/education

Cope, B., \& Kalantzis, M. (2000). Multiliteracies: Literacy learning and the design of social futures. London: Routledge.

Critical Digital Literacy Project. (2018). Critical Digital Literacy Project. Retrieved from https://thecritical digitalliteracyproject.com

Daniels, J., Jacobsen, A., Varnhagen, C., \& Friesen, S. (2013). Barriers to systemic, effective, and sustainable technology use in high school classrooms. Canadian Journal of Learning and Technology, 39(4), 1-14.

Dei, G., James, I., James-Wilson, S., Karumanchery, L., \& Zine, J. (2000). Removing the margins: The challenges and possibilities of inclusive schooling. Toronto: Canadian Scholar's Press.

Denzin, N., \& Lincoln, Y. (2011). The Sage handbook of qualitative research (4th ed.). Thousand Oaks, CA: Sage.

Dwyer, B. (2016). Teaching and learning in the global vil- lage: Connect, create, collaborate, and communicate. The Reading Teacher, 70(1), 131-136.

Freire, P. (2000). Pedagogy of the oppressed. New York, NY: Continuum Press.

Goodman, S. (2003). Teaching youth media: A guide to literacy, video production and social change. New York, NY: Teachers College Press.

Goodman, S. (2018). It's not about grit: Trauma, inequality, and the power of transformative teaching. New York, NY: Teachers College Press.

Hagood, M. (2013). So now you know. What are you going to do about it? In J. Ávila \& J. Zacher Pandya (Eds.), Critical literacies as social praxis: Intersections and challenges (pp. 219-224). New York, NY: Peter Lang.

Harste, J. (2014). The art of learning to be critically literate. Language Arts, 92, 90-102.

Hobbs, R. (2017). Create to learn: Introduction to digital literacy. Malden, MA: Wiley Blackwell.

Hobbs, R., \& Coiro, J. (2016). Everyone learns from everyone: Collaborative and interdisciplinary professional development in digital literacy. Journal of Adult and Adolescent Literacy, 59(6), 623-629.

Hoechsmann, M., \& DeWaard, H. (2015). Mapping digital literacy policy and practice in the Canadian education landscape. Ottawa: Media Smarts. Retrieved from http://mediasmarts.ca/teacherresources/digitalliteracy-framework/mapping-digital-literacy-policypractice-canadian-educationlandscape

Hutchison, D. (2012). The student filmmaker. What works? Research into Practice. Toronto: Ontario Ministry of Education.

Ito, M., Horst, H. A., Bittanti, M., Boyd, D., HerrStevenson, B., \& Lange, P. (2008). White paper. Living and learning with new media: Summary of findings from the digital youth project. Chicago, IL: The John P. and Catherine T. MacArthur Foundation.

Jenkins, H., Purushotma, R., Weigel, M., Clinton, K., \& Robison, A. (2006). Confronting the challenges of participatory culture: Media education for the 21st century. Cambridge, MA: MIT Press.

Johnson, M., Riel, R., \& Froese-Germain, B. (2016). Connected to learn: Teachers' experiences with networked technologies in the classroom. Ottawa: Media Smarts \& The Canadian Teacher's Federation.

Knobel, M., \& Kalman, J. (2016). Teacher learning, digital technologies, and new literacies. In M. Knobel \& J. Kalman (Eds), New literacies and teacher learning: Professional development and the digital turn (pp. 1-20). New York, NY: Peter Lang.

Knoble, M., \& Lankshear, C. (2010). DIY media: Creating, sharing and learning with new media. New York, NY: Peter Lang.

Kress, G. (2010). Multimodality: A social semiotic approach to contemporary communication. New York, NY: Routledge.

Lange, P. (2014). Kids on YouTube: Technical identities and digital literacies. Walnut Creek, CA: Left Coast Press. 
Lankshear, C., \& Knobel, M. (2011). The new literacies: Everyday practices and social learning (3rd ed.). Berkshire: McGraw Hill.

Leu, D., Kinzer, C., Coiro, J., Castek, J., \& Henry, L. (2013). New literacies: A dual-level theory of the changing nature of literacy, instruction, and assessment. In D. Alvermann, N. Unrau, \& R. Ruddell (Eds.), Theoretical models and processes of reading (6th ed., pp. 1150-1181). Newark, NJ: International Reading Association.

Leu, D., Forzani, E., Timbrell, N., \& Maykel, C. (2015). Seeing the forest, not the trees: Essential technologies for literacy in the primary-grade and upper elementary-grade classroom. Journal of Adolescent and Adult Literacy, 69(2), 139-145.

Lotherington, H., Fisher, S., Jenson, J., \& Lindo, L. (2016). Professional development from the inside out: Redesigning learning through collaborative action research. In M. Knobel \& J. Kalman (Eds.), New literacies and teacher learning: Professional development and the digital turn (pp. 65-87). New York, NY: Peter Lang.

Manjou, F. (2018, February 14). Welcome to the posttext future. The New York Times. Retrieved from https://www.nytimes.com/interactive/2018/02/09/ technology/the-rise-of-avisual-internet.html

Media Smarts. (2016). Use, understand \& create: A digital literacy framework for Canadian schools, $K-12$. Ottawa: MediaSmarts.

Media Smarts. (2018). Digital and media literacy outcomes by province and territory. Retrieved from http://mediasmarts.ca/teacher-resources/digitaland-media-literacy-outcomes-province-territory

Miller, S. (2010). Towards a multimodal literacy pedagogy: Digital video composing as 21st century literacy. In P. Albers \& J. Sanders (Eds.), Literacies, art, and multimodality (pp. 254-281). UrbanaChampaign, IL: National Council of Teachers of English.

Miller, S. (2013). A research metasynthesis on digital video composing in classrooms: An evidence-based framework toward a pedagogy for embodied learning, Journal of Literacy Research, 45(4), 386-430.

Miller, S., \& McVee, M. (2012). Multimodal composing: The essential 21st century literacy. In S. Miller \& M. McVee (Eds.), Multimodal composing in classrooms: Learning and teaching for the digital world. New York, NY: Routledge.

Mills, K. (2010). A review of the 'digital turn' in the new literacy studies. Review of Educational Research, 80(2), 246-271.

New London Group. (1996). A pedagogy of multiliteracies: Designing social futures. Harvard Educational Review, 66(1), 60-93.

Ontario Ministry of Education. (2006). The Ontario curriculum, $k-8$ language arts. Toronto: Ontario Ministry of Education.

Ontario Ministry of Education. (2009a). The Ontario cur- riculum, grades 1-8 the arts. Toronto: Ontario Ministry of Education.

Ontario Ministry of Education. (2009b). Ontario's equity and inclusive education strategy. Toronto: Ontario Ministry of Education.

Ontario Ministry of Education. (2015). Literacy for a connected world. Capacity building K-12 monograph. Toronto: Ontario Ministry of Education.

Ontario Ministry of Education. (2016). 21st century competencies: Foundation document for discussion. Toronto: Ontario Ministry of Education.

Pink, S. (2007). Doing visual ethnography (2nd ed.). Thousand Oaks, CA: Sage

Ratner, E., \& Friesem, Y. (2018). Civic media as a cultural dialogue: A professional development journey of Arab and Jewish teachers via documentary filmmaking in Israel. Journal of Media Literacy, 65(1/2), 13-18.

Ratto, M., \& Boler, M. (2014). DIY citizenship: Critical making and social media. Cambridge, MA: The MIT Press.

Rose, G. (2012). Visual methodologies: An introduction to researching with visual materials ( $3 \mathrm{rd}$ ed.). Thousand Oaks, CA: Sage.

Sanford, K., Rogers, T., \& Kendrick, M. (2014). An introduction to everyday youth literacies: Critical perspectives in new times. In K. Sanford, T. Rogers, \& M. Kendrick (Eds.), Everyday youth literacies: Critical perspectives for new times (pp. 1-13). New York, NY: Springer.

Simon, R. (2013). Literacy teacher education as critical inquiry. In C. Kosnik, J. Rowsell, P. Williamson, R. Simon, \& C. Beck (Eds.), Literacy teacher educators: Preparing teachers for a changing world (pp. 135-148). Rotterdam: Sense Publishers.

Spires, H. (2018). Call for papers. Critical perspectives on digital literacies: Creating a path forward. Media and Communication. Retrieved from https://www. cogitatiopress.com/mediaandcommunication

Spires, H, Hervey, L., Morris, G., \& Stelpflug, C. (2012). Engergizing project-based inquiry: Middle grade students read, write, and create videos. Journal of Adolescent and Adult Literacy, 55(6), 483-493.

Spires, H., Paul, C., Himes, M., \& Yuan, C. (2018). Crosscultural collaborative inquiry: A collective case study with students from China and the US. International Journal of Educational Research, 91, 28-40.

Steeves, V. (2014). Young Canadians in a wired world, phase III: Life online. Ottawa: Media Smarts.

Vasquez, V. (2013). Living and learning critical literacy in the university classroom. In C. Kosnik, J. Rowsell, P. Williamson, R. Simon, \& C. Beck (Eds.), Literacy teacher educators: Preparing teachers for a changing world (pp. 79-92). Rotterdam: Sense Publishers.

Vasquez, V., \& Branigan Felderman, C. (2013). Technology and critical literacy in early childhood. New York, NY: Routledge.

Watt, D. (2011a). From the streets of Peshawar to the 
cover of Maclean's Magazine: Reading images of Muslim women as 'currere' to interrupt gendered Islamophobia. Journal of Curriculum Theorizing, 27(1), 64-86.

Watt, D. (2011b). Juxtaposing 'sonare' and 'videre' midst curricular spaces: Negotiating Muslim, female identities in the discursive spaces of schooling and visual media cultures (Unpublished doctoral dissertation). University of Ottawa, Ottawa, Canada.

Watt, D. (2012). The urgency of visual media literacy in our post-9/11 world: Reading images of Muslim women in the print news media. Journal of Media Literacy Education, 4(1), 32-41.

Watt, D. (2016a). Toward the internationalization of teacher education for social justice: Interrogating our relation to difference in-between here and there. In S. Sharma \& J. Phillion (Eds.), Internationalizing teacher education for social justice: Theory, research, and practice. Charlotte, NC: Information Age Publishing.

Watt, D. (2016b). Muslim female students assert their identities in-between family, schooling, and the mass media. Journal of Family Diversity in Education, 1(1), 21-36.

Watt, D. (2017). New literacies and global education: Video production in teacher education as a critical digital literacy practice. Paper presented at the world education research association annual meeting, The Education University of Hong Kong, Hong Kong.
Watt, D. (2018). Video production in teacher education: Negotiating New Literacies practices in-between the classroom and our networked world. Paper presented at the international conference on education and global studies, Osaka, Japan.

Watt, D., Abdulqadir, K., Hujaleh, H., \& Siyad, F. (2019). "Three things you should know about my hijab": The art of youth media activism on YouTube. Journal of Literacy and Technology, 20(1), 252-271.

Watt, D., Abdulqadir, K., Siyad, F., \& Hujaleh, H. (2019). Engaging difference in the digital age: Learning with/from three Somali-Canadian, Muslim, female YouTubers. In S. Sharma \& A. Lazar (Eds.), Rethinking 21st century diversity in teacher preparation, K-12 education, and school policy: Theory, research, and practice (pp. 221-239). New York, NY: Springer Publishing.

Williamson, P. (2013). Introduction. In C. Kosnik, J. Rowsell, P. Williamson, R. Simon, \& C. Beck (Eds.), Literacy teacher educators: Preparing teachers for a changing world (pp. 1-4). Rotterdam: Sense Publishers.

Willinksy, J. (2001). After literacy: Essays. New York, NY: Peter Lang.

Wohlwend, K. (2013). Litearcy playshop: New literacies, popular media, and play in the early childhood classroom. New York, NY: Teachers College Columbia University.

\section{About the Author}

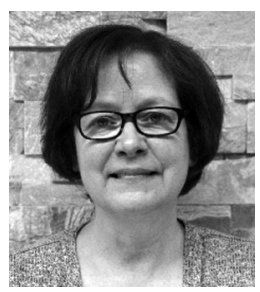

Diane Watt is an Adjunct Professor in the Faculty of Education at the University of Ottawa. She teaches graduate and undergraduate courses in literacies, digital technologies, curriculum, global education, feminist perspectives, social contexts of education, and qualitative inquiry. Watt has also held positions as a visiting scholar at the Institute for Feminist and Gender Studies at the University of Ottawa, and a Postdoctoral Scholar at the Werklund School of Education at the University of Calgary. 